\title{
Comparison of the Pregnancy Characteristics and Outcomes Between Syrian Immigrants and Local Turkish Women: Large Cohort Multicenter Study
}

Özgün Araştırma Research Article

\author{
Suriyeli Mülteciler ve Yerel Türk Vatandaşları Arasındaki \\ Gebelik Özellikleri ve Sonuçlarının Karşılaştırılması: \\ Çok Merkezli Geniş Kohort Çalışma
}

Received/Geliş: 24.09.2020

Accepted/Kabul: 27.01.2021

Published Online: 18.08 .2021

Seçil Karaca Kurtulmuş Izmir Katip Çelebi Üniversitesi Atatürk Eğitim Araştırma Hastanesi Kadın Hastalıkları ve Doğum Kliniği, Izmir, Türkiye secilkurtulmus@yahoo.com ORCID: 0000-0001-8340-7364

E. Şahin Güleç 0000-0003-0327-5707 Sağlık Bilimleri Üniversitesi Tepecik Hastanesi, Kadın Hastalıkları ve Doğum Kliniği, izmir, Türkiye

E.B. Gür 0000-0002-1976-8795 İzmir Katip Çelebi Üniversitesi Atatürk Eğitim Araştırma Hastanesi Kadın Hastalıkları ve Doğum Kliniği, izmir, Türkiye

cite as: Karaca Kurtulmuş $\mathrm{S}$, Şahin Gülec $E$, Gür EB. Comparison of the pregnancy characteristics and outcomes between Syrian immigrants and local Turkish women: large immigrants and local Turkish women: large
cohort multicenter study. Tepecik Eğit. ve cohort multicenter study. Tepecik
Araşt. Hast. Dergisi. 2021;31(2):181-6.
Seçil Karaca Kurtulmuş®, Ebru Şahin Güleç®, Esra Bahar Gür ${ }^{\oplus}$

\section{ABSTRACT}

Objective: The aim of the present study is to compare Syrian immigrants and local Turkish women in terms of pregnancy characteristics and its outcomes.

Methods: In a large cohort, multicenter, retrospective study, we obtained data from births that occurred in three hospitals in the Metropolitan Municipality of Izmir and Aydin Province between October 1, 2009 and June 1, 2019. We compared 11036 Syrian immigrants and local Turkish women in terms of their demographic features, perinatal, and neonatal outcomes.

Results: Pregnant women were significantly younger, and the number of adolescent pregnancies (maternal age $<19)$ was significantly higher in the Syrian immigrant group $(p<0.01$, and $p<0.01$, respectively). The number of previous pregnancies was higher among Syrian immigrant pregnant women $(p<0.01)$. Cesarean Section $(C / S)$ and interventional delivery rates were higher in Turkish pregnant women, and $C / S$ delivery indications were significantly different between the groups $(p<0.05$, and $p<0.01$, respectively). Preterm birth rates ( $<37$ gestational weeks) were higher in the Syrian immigrants, whereas the rates of low birth weight (LBW) $(<2500$ gr) were higher in the Turkish women ( $p<0.05$, and $p<0.05$, respectively). Also, the mean newborn birth weight and head circumference of the newborns were higher in the Turkish women, whereas the birth length of newborns was higher in the Syrian immigrants $(p<0.01, p<0.01$, and $p<0.01$, respectively).

Conclusion: In the present study, compared to local Turkish pregnant women, pregnancy characteristics and the perinatal outcomes of the Syrian immigrant women and their neonates had different characteristics. Moreover, the types and indications of delivery of Syrian immigrants differed from those of Turkish pregnant women. The findings of our large cohort study can contribute to the improvement of health policies in Turkey and other countries hosting Syrian immigrants.

Keywords: Pregnancy characteristics, obstetric outcome, syrian immigrants

Öz

Amaç: Çalışmanın amacı Türkiye'de bulunan Suriyeli mülteciler ile Türk vatandaşlarının gebeliklerine ait özellikler ve gebelik sonuçlarının karşılaştırılmasıdır.

Yöntem: Bu geniş kohortlu, çok merkezli, retrospektif çalışmada 1 Ocak 2009 ve 1 Haziran 2019 tarihleri arasında Aydın ve Izmir illerinde bulunan üç hastaneden elde edilen veriler analiz edilmiștir. Çalıșmada 11036 Suriyeli mülteci ve 141442 Türk vatandaşına ait demografik veriler, obstetrik öykü, obstetrik ve neonatal sonuçlar kıyaslandı. Bulgular: Türk vatandaşlarına kıyasla Suriyeli mülteci gebeler daha gençti ve Suriyeli grupta adölesan gebelikler (anne yaşı<19) daha fazlaydı (sırasıyla $p<0,01 ; p<0,01)$. Suriyeli gebeler arasında parite daha fazlaydı $(p<0,01)$. Türk vatandaşları arasında sezaryen $(C / S)$ ve müdahaleli doğumlar daha fazlaydı ve iki grup arasında sezaryen endikasyonları istatistiksel olarak farklıydı (sırasıyla $p<0,05, p<0,01$ ). Preterm doğum ( $<37$ hafta gebelik) oranı Suriyeli gebelerde daha fazla bulurken, düşük doğum ağırıklı infant (<2500 gr) oranı Türklerde daha yüksekti (sırasıyla $p<0,05, p<0,05$ ). Ayrıca yeni doğanlarda ortalama doğum ağırlığı ve baş çevresi Türkler'de, yeni doğan boy uzunlu$\breve{g u}$ ise Suriyeli grubunda anlamlı olarak daha fazlaydı (sırasıyla $p<0.01, p<0.01$ ).

Sonuç: Bu çalışmanın sonucunda yerel Türk vatandaşı gebelere kıyasla Suriyeli mülteci gebelerin gerek gebelik özelliklerinin, gerekse gebelik sonuçlarının farklı özelliklere sahip olduğu görüldü. Dahası, Suriyeli mülteci gebelerin doğum şekilleri ve endikasyonlarının da farklılık gösterdiği ortaya kondu. Geniş katılımlı bu çalışmanın bulguları, Suriyeli mültecilere ev sahipliği yapan Türkiye ve diğer ülkelerin sağılk politikalarının planlanmasına katkı sağlayabilir.

Anahtar kelimeler: Gebelik özellikleri, obstetrik sonuçlar, suriyeli mülteciler

(C) Telif hakkı TC. Să̆lık Bakanlığı İmir Tepecik Eğit. ve Arastt. Hastanesi. Logos Tip Yayınclık tarafindan yayınlanmaktadır.

Bu dergide yayınlanan bütün makaleler Creative Commons Attf-GayriTicari 4.0 Uluslararası Lisansı ile lisanslanmıştr.

(c) Copyright Association of Publication of the T.C. Ministry of Health İmir Tepecik Education and Research Hospital.

This journal published by Logos Medical Publishing.

Licenced by Creative Commons Attribution-NonCommercial 4.0 International (CC BY) 


\section{INTRODUCTION}

After the civil war in Syria, which began in March 2011, about 7 million Syrian citizens had to immigrate to other countries. Of these, about 5 million migrated to neighboring countries. Over 3,6 million registered Syrian immigrants live in Turkey and Turkey are hosting the statistically significantly greatest number of Syrian immigrants in the World (1). Of the immigrants dwelling in Turkey, 45,85\% are women, and $50,33 \%$ of these women are of reproductive age (between 15-44 years old) (2). It is a known fact that due to language and cultural barriers, economic difficulties, and poor nutritional status, refugees are at increased risk for poorer pregnancy outcomes all around the World. The literature from different countries showed that refugee populations often encounter poor perinatal outcomes such as preterm birth, low birth weight, increased incidence of Cesarean section (C/S) deliveries, bleeding during delivery, and puerperal infections ${ }^{(3-7)}$.

Numerous studies exist in the literature that compare Syrian immigrants, and local citizens in terms of pregnancy outcomes ${ }^{(8-13)}$. To our knowledge, this multicenter study has the largest-scale cohort study performed up to now. The present study aimed to compare Syrian immigrants and local Turkish women in terms of the pregnancy characteristics and perinatal outcomes so as to obtain further medical data related to refugees and contribute to the improvement of health policies.

\section{MATERIAL and METHODS}

We planned a retrospective study using the birth data of the newborns delivered October 1, 2009 and June 1, 2019 in three hospitals ie. Izmir Katip Celebi University, Atatürk Training and Research Hospital Department of Obstetrics and Gynecology, University of Health Sciences, Izmir Tepecik Educational and Research Hospital, and Aydın Maternity and Childrens' Hospital. The ethical approval was obtained from the local ethics committee, and permission to use archives was obtained from the management of all three hospitals (approval date:.05.30.2019/ approval number:271).

All data related to maternal age, number of parities, duration of pregnancy, multiple gestations, modes of delivery, indications of cesarean section (C/S) deliveries, birth weight, birth length, head circumference, sex, 1-minute and 5- minute Apgar scores, and vitality status of newborns were obtained from medical records. We recorded all deliveries that occurred in all three hospitals within the specified dates. We grouped the data according to the nationality of the women. We excluded 433 women who were not Turkish or Syrian citizens and 429 women with missing data were not included in the study.. The flow chart of the study is depicted in Figure 1.

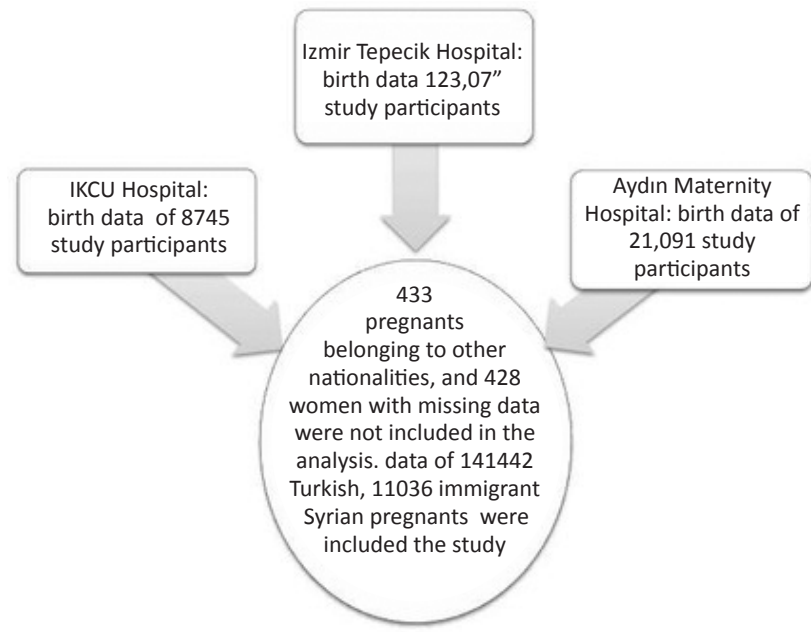

Figure 1. The flowchart of the study.

\section{Statistical Analysis:}

The data were expressed as mean \pm standard deviation or median (range). The independent samples t-test, Mann-Whitney $U$ test, and $\chi^{2}$ test were used to compare groups. $\mathrm{P}<0.05$ was considered statistically significant. Statistical analyses were performed using SPSS version 20.0 (IBM. Armonk, NY, USA).

\section{RESULTS}

We evaluated the birth data of 141,442 Turkish and 11,036 Syrian mothers and infants. The Syrian immigrant pregnant women were significantly 
S. Karaca Kurtulmuş et al.,Comparison of the Pregnancy Characteristics and Outcomes Between Syrian Immigrants and Local Turkish Women: Large Cohort Multicenter Study

younger, and the adolescent pregnancy (maternal age $<19)$ rate was significantly higher among Syrian immigrants $(p<0.01, p<0.01)$. The number of previous pregnancies was significantly higher in the Syrian immigrants than local Turkish pregnant women $(p<0.01) . C / S$ and interventional delivery rates and also primary $\mathrm{C} / \mathrm{S}$ delivery rates were significantly higher in Turkish pregnant women $(p<0.05, p<0.05$, and $p<0.05$, respectively). Gestational age at birth was significantly lower among the Syrian immigrants $(p<0,01)$. The rates of preterm birth $(<37$ gestational week) was significantly higher in the Syrian immigrants. In contrast, the incidence of low birth weight (LBW) (<2500 gr) was significantly higher in Turkish women. Post-term birth ( $>42$ gestational weeks) rates were significantly higher in the Syrian immigrants $(p<0.05)$. Newborn birth weight and the number of macrosomic newborns ( $>4000 \mathrm{gr}$ ) were significantly higher in Turkish women $(p<0,01$, and $p<0,05$, respectively). Also, the head circumference of the newborns of Turkish women was significantly larger, whereas birth lengths of Syrian newborns were significantly higher $(p<0.01$, and $p<0.01$, respectively). The 1 and 5 minute Apgar scores of the newborns were significantly lower in Turkish women ( $p<0,01$, and $p<0,01$, respectively) (Table 1$)$.

The $\mathrm{C} / \mathrm{S}$ delivery indications were significantly different between the two groups $(p<0.01)$. Among $\mathrm{C} / \mathrm{S}$ delivery indications, the rates of fetal distress, placenta previa, non-progressive labor, large for gestational age, macrosomic fetus, preeclampsia,

Table 1. Characteristics and maternal-neonatal outcomes of Syrian and Turkish pregnants. $p<0.05$ is istatistically significans.

\begin{tabular}{|c|c|c|c|}
\hline & $\begin{array}{l}\text { Turkish women } \\
n=141442\end{array}$ & $\begin{array}{l}\text { Syrian immigrants } \\
n=11036\end{array}$ & P Value \\
\hline $\begin{array}{l}\text { Maternal Age } \\
\text { (min-max) }\end{array}$ & $\begin{array}{l}27.53 \pm 5.89 \\
(12-50)\end{array}$ & $\begin{array}{l}24.46 \pm 5.92 \\
(12-49)\end{array}$ & $<0.01$ \\
\hline Adolescent pregnancy (maternal age $<19$ ) & $\begin{array}{c}5384 \\
3,80 \%\end{array}$ & $\begin{array}{c}1484 \\
13,44 \%\end{array}$ & $<0.05$ \\
\hline $\begin{array}{l}\text { Number of pregnancies (mean } \pm S D \text { ) } \\
\text { Mode of delivery }\end{array}$ & $1.85 \pm 1.29$ & $2.29 \pm 1.56$ & $\begin{array}{l}<0.01 \\
<0.01\end{array}$ \\
\hline Vaginal delivery $(n, \%)$ & $\begin{array}{l}67925 \\
48,02 \%\end{array}$ & $\begin{array}{l}6854 \\
62.10 \%\end{array}$ & $<0.05$ \\
\hline Cesarian Section delivery ( $n, \%)$ & $\begin{array}{l}72841 \\
51,49 \%\end{array}$ & $\begin{array}{c}4159 \\
37.68 \%\end{array}$ & $<0.05$ \\
\hline Interventional delivery $(n, \%)$ & $\begin{array}{c}676 \\
0,47 \%\end{array}$ & $\begin{array}{c}23 \\
0.20 \%\end{array}$ & $<0.05$ \\
\hline Primary Cesarian Section $(n, \%)$ & $\begin{array}{c}28238 \\
57.63 \%\end{array}$ & $\begin{array}{c}2137 \\
55.09 \%\end{array}$ & $<0.01$ \\
\hline Multiple gestation ( $n, \%)$ & $\begin{array}{c}4248 \\
3 \%\end{array}$ & $\begin{array}{r}334 \\
3 \%\end{array}$ & 0.89 \\
\hline Mean gestational week $(n, \%)$ & $38.34 \pm 2.66$ & $38.09 \pm 2.48$ & $<0.01$ \\
\hline$<37$ gestational week $(n, \%)$ & $\begin{array}{c}17135 \\
12.11 \%\end{array}$ & $\begin{array}{c}1773 \\
16.06 \%\end{array}$ & $<0.05$ \\
\hline$>42$ gestational week $(n, \%)$ & $\begin{array}{c}106 \\
0,6 \%\end{array}$ & $\begin{array}{c}19 \\
1.1 \%\end{array}$ & $<0.05$ \\
\hline Birth weight (gr) (mean $\pm S D)$ & $3147.61 \pm 657.14$ & $3071.42 \pm 458.69$ & $<0.01$ \\
\hline $\begin{array}{l}\text { Low birth weight (LBW), } \\
<2500 \text { gr, }(n, \%)\end{array}$ & $\begin{array}{c}16795 \\
11,87 \%\end{array}$ & $\begin{array}{c}1241 \\
11,24 \%\end{array}$ & $<0.05$ \\
\hline$>4000 \mathrm{gr}(\mathrm{n}, \%)$ & $\begin{array}{l}7606 \\
5.4 \%\end{array}$ & $\begin{array}{l}322 \\
2.9 \%\end{array}$ & $<0.05$ \\
\hline Fetal sex & & & \\
\hline Male $(n, \%)$ & $\begin{array}{l}71881 \\
50.82 \%\end{array}$ & $\begin{array}{l}5572 \\
50.48 \%\end{array}$ & $>0.05$ \\
\hline Female $(n, \%)$ & $\begin{array}{l}69.512 \\
49.15 \%\end{array}$ & $\begin{array}{c}5454 \\
49.42 \%\end{array}$ & $>0.05$ \\
\hline Ambigious genitalia (n) & $\begin{array}{c}49 \\
0.03 \%\end{array}$ & $\begin{array}{c}10 \\
0.09 \%\end{array}$ & $>0.05$ \\
\hline Newborn head circumference $(\mathrm{cm})($ mean $\pm S D)$ & $34.39 \pm 2.37$ & $34.23 \pm 2.37$ & $<0.01$ \\
\hline Newborn length $(\mathrm{cm})($ mean $\pm S D)$ & $48.95 \pm 3.47$ & $48.99 \pm 3.01$ & $<0.01$ \\
\hline Stillbirth $(n, \%)$ & $1848,1.30 \%$ & $131,1.18 \%$ & 0.28 \\
\hline 1 min- Apgar score (mean $\pm S D)$ & $7.07 \pm 1.02$ & $7.18 \pm 1.06$ & $<0.01$ \\
\hline 5 min-Apgar score (mean $\pm S D)$ & $8.02 \pm 0.88$ & $8.14 \pm 0.95$ & $<0.01$ \\
\hline
\end{tabular}


Table 2. Indications for cesarean section in pregnant women with Syrian and Turkish citizens. $P<0.05$ is istatistically significant.

\begin{tabular}{|c|c|c|c|}
\hline & $\begin{array}{l}\text { Turkish women } \\
n=60619\end{array}$ & $\begin{array}{l}\text { Syrian immigrants } \\
\qquad \mathrm{n}=4157\end{array}$ & P Value \\
\hline Indications for cesarean section & & & $<0.01$ \\
\hline Repeated cesarean sections ( $n, \%)$ & $\begin{array}{c}27508 \\
45,37 \%\end{array}$ & $\begin{array}{c}2118 \\
50.95 \%\end{array}$ & $<0.05$ \\
\hline Cephalopelvic discrepancy (n, \%) & $\begin{array}{l}4592 \\
7.57 \%\end{array}$ & $\begin{array}{c}332 \\
7,98 \%\end{array}$ & $>0.05$ \\
\hline Fetal distress ( $n, \%)$ & $\begin{array}{c}10988 \\
18,12 \%\end{array}$ & $\begin{array}{c}638 \\
15.34 \%\end{array}$ & $<0.05$ \\
\hline Breech presentation ( $\mathrm{n}, \%)$ & $\begin{array}{l}3024 \\
4.98 \%\end{array}$ & $\begin{array}{c}249 \\
5,98 \%\end{array}$ & $<0.05$ \\
\hline Other malpresentations ( $\mathrm{n}, \%)$ & $\begin{array}{c}390 \\
0.64 \%\end{array}$ & $\begin{array}{c}56 \\
1.34 \%\end{array}$ & $<0.05$ \\
\hline Placenta anomalies (P.Previa, Decollement) (n, \%) & $\begin{array}{c}1220 \\
2,01 \%\end{array}$ & $\begin{array}{c}60 \\
1.44 \%\end{array}$ & $<0.05$ \\
\hline Non-progressive labor ( $\mathrm{n}, \%)$ & $\begin{array}{l}4959 \\
8.18 \%\end{array}$ & $\begin{array}{c}240 \\
5.77 \%\end{array}$ & $<0.05$ \\
\hline Large for gestational age: Macrosomic fetüs (n, \%) & $\begin{array}{l}1974 \\
3.25 \%\end{array}$ & $\begin{array}{c}87 \\
2.09 \%\end{array}$ & $<0.05$ \\
\hline Multiple gestations ( $n, \%)$ & $\begin{array}{c}2406 \\
3,96 \%\end{array}$ & $\begin{array}{c}236 \\
5.67 \%\end{array}$ & $<0.05$ \\
\hline Eclampsia (n, \%) & $\begin{array}{c}23 \\
0.03 \%\end{array}$ & $\begin{array}{c}2 \\
0.04 \%\end{array}$ & $>0.05$ \\
\hline Pre-eclampsia and other hypertensive disorders ( $n, \%)$ & $\begin{array}{l}1644 \\
2.71 \%\end{array}$ & $\begin{array}{c}70 \\
1.68 \%\end{array}$ & $<0.05$ \\
\hline Maternal disorders (n, \%) & $\begin{array}{c}480 \\
0.79 \%\end{array}$ & $\begin{array}{c}18 \\
0.43 \%\end{array}$ & $<0.05$ \\
\hline IVF pregnancy $(n, \%)$ & $\begin{array}{c}174 \\
0.28 \%\end{array}$ & $\begin{array}{c}1 \\
0.02 \%\end{array}$ & $<0.05$ \\
\hline Fetal anomalies (n, \%) & $\begin{array}{c}644 \\
1.06 \%\end{array}$ & $\begin{array}{c}26 \\
0.62 \%\end{array}$ & $<0.05$ \\
\hline Prolapsus of umbilical cord (n, \%) & $\begin{array}{c}121 \\
0.19 \%\end{array}$ & $\begin{array}{c}7 \\
0.16 \%\end{array}$ & $>0.05$ \\
\hline
\end{tabular}

and other hypertensive disorders, maternal disorders, in vitro fertilization (IVF) pregnancy, and fetal anomalies were higher in Turkish women. On the other hand, the rates of repeated $\mathrm{C} / \mathrm{S}$ deliveries, breech presentation, and other malpresentations, multiple gestations were higher in the Syrian immigrants (Table 2).

\section{DISCUSSION}

Our study investigated the birth data regarding the previous ten years of 3 hospitals in two provinces located in western Turkey, where approximately 5 million people live. We compared the Syrian immigrants with local Turkish women in terms of obstetric and neonatal outcomes. To our knowledge, this is the most comprehensive study performed on this subject till now. In our study, statistically significant differences between the two groups were observed.
We observed that Syrian immigrant pregnant women were significantly younger, and the number of adolescent pregnancies was more numerous among them when compared with Turkish pregnant women. Similar to our study, the mean maternal age of Syrian immigrant pregnant women was lower in the two studies conducted in Turkey ${ }^{(9,10)}$. Furthermore, the adolescent pregnancy rates were higher in Syrian immigrants than local Turkish women in two studies conducted by Erenel et al. and by Turkay et al. ${ }^{(9,13)}$ ( $14.5 \%$ vs. $5.3 \%, 10.8 \%$ vs. $2.4 \%, p<0.01, p<0.01$, respectively). Adolescent pregnancies are related to increasing rates of poor perinatal outcomes. Gestational hypertension, anemia, low gestational weight gain, preterm birth, LBW, and increased infant and perinatal mortality rates are more commonly observed among pregnant adolescents ${ }^{(14,15)}$. According to the 2018 data of The World Health Organization (WHO), the incidence of adolescent pregnancy is increasing worldwide (up to $11.5 \%$ in 
S. Karaca Kurtulmuş et al.,Comparison of the Pregnancy Characteristics and Outcomes Between Syrian Immigrants and Local Turkish Women: Large Cohort Multicenter Study

Africa) ${ }^{(16)}$. In our study, the average rate of adolescent pregnancy among Syrian migrants was $13.4 \%$, ie. above the World average.

Our study found that the $\mathrm{C} / \mathrm{S}$ delivery rates of both groups were higher than the rates recommended by WHO, which is about $10-15 \%$, and $\mathrm{C} / \mathrm{S}$ delivery rates were significantly higher among local Turkish women. Our finding was in line with the previous study made in Bursa, Turkey ${ }^{(10)}$. Several studies reported higher $\mathrm{C} / \mathrm{S}$ rates among refugees in different countries ${ }^{(3,7)}$. In their study, Karin et al. ${ }^{(17)}$ reported higher $\mathrm{C} / \mathrm{S}$ delivery rates among Syrian refugees than Lebanese women. They observed that refugees had a high incidence of birth and health complications diagnosed at the time of delivery that often required emergent $\mathrm{C} / \mathrm{S}$ delivery. We also found that primary $\mathrm{C} / \mathrm{S}$ delivery rates were significantly higher among local Turkish women. Similarly, in their study, Erenel et al. (9) reported lower cesarean rates in nulliparous Syrian women. We thought that lower total and primary $\mathrm{C} / \mathrm{S}$ delivery rates among Syrian immigrants might be associated with cultural differences between the nations and may be due to the insistence of Syrian women to have vaginal rather than $\mathrm{C} / \mathrm{S}$ delivery.

In our study, the most common cause for $\mathrm{C} / \mathrm{S}$ deliveries was the history of previous $\mathrm{C} / \mathrm{S}$ delivery in both groups. The $\mathrm{C} / \mathrm{S}$ delivery rates due to previous repeated $\mathrm{C} / \mathrm{S}$ deliveries were significantly higher in the Syrian immigrant group. Similarly, with our reports, Karin et al. ${ }^{(17)}$ and Alnuaimi et al. ${ }^{(3)}$ reported that the history of a repeated $\mathrm{C} / \mathrm{S}$ was the most common reason for $\mathrm{C} / \mathrm{S}$ deliveries among the Syrian immigrants in Lebanon and Jordan.

Rates of $\mathrm{C} / \mathrm{S}$ delivery due to fetal anomaly, placental anomalies (placenta previa, ablatio placenta), preeclampsia, and other hypertensive disorders, IVF pregnancies, and maternal disorders were significantly higher in the Turkish group. All these mentioned indications are related to high-risk pregnancies, and usually, state and private hospitals refer patients who have these risk factors to tertiary clinics, which increases C/Sdelivery rates. Additionally,
$\mathrm{C} / \mathrm{S}$ delivery rates due to arrested labor and fetal macrosomia were significantly higher in Turkish women. This situation may be due to increased diabetes mellitus (DM) and gestational DM (GDM) prevalence in the Turkish population ${ }^{(18,19)}$. In two other studies, Demirci et al. ${ }^{(10)}$ and Güngör et al. ${ }^{(11)}$ reported higher GDM rates for Turkish women when compared with Syrian immigrants.

In our study, the mean gestational week at delivery was significantly lower, and the preterm birth rates (<37 gestational weeks) were significantly higher in the Syrian immigrant group. These findings were in line with several studies conducted in different clinics, either in Turkey or other countries ${ }^{(12,6)}$. In addition to this, the mean birth weight of babies delivered by Syrian immigrants was significantly lower than Turkish controls which may be related to either higher preterm birth rates among Syrian women or ethnic differences. However, interestingly, the rate of LBW was significantly higher in the Turkish group. As preeclampsia, hypertensive disorders, and other maternal disorders were more common in the Turkish group, fetal growth restriction due to these conditions could be the reason for LBW. Indeed nutritional deficiency and poor compliance with antenatal care could be the reason for preterm births among Syrian refugees in Turkey.

The limitations of our study: Our study had a retrospective design, and we analyzed the data of over 152.000 patients. For that reason, we were not able to scan the data, related to the number of antenatal visits and laboratory parameters.

The strengths of our study: To our knowledge, our study has the largest -scale cohort study which compares the pregnancy outcomes of immigrant women with those of the local Turkish women. Thus our results can provide more robust and qualified information to the government, which can help the organization of health care policies about immigrant women.

In conclusion, Syrian refugees in our country who are 
victims of civil war seem to have significantly different obstetric outcomes from local native population either because of their ethnic and cultural differences or their challenging living conditions. All these factors are associated with adverse obstetric and neonatal outcomes. Therefore, the results of our study may contribute to the improvement of health care policies that would help alleviate the situation regarding refugee women.

Ethics Committee Approval: Izmir Katip Celebi University Non-Invasive Clinical Research Ethics Committee approval was obtained (03.10.2018/289).

Conflict of Interest: There is no conflict of interest between the authors participating the study.

Funding: No financial support was received for the study.

Informed Consent: As it was a retrospective study informed consent was not obtained.

\section{REFERENCES}

1. United Nations Refugee Agency. Inter-agency Information Sharing Portal. 2016; Apr.

2. Turkish Ministry of Interior General Directorate of Immigration, migration statistics, temporaray protection 2019;Sep.

3. Alnuaimi K, Kassab M, Ali R, Mohammad K, Shattnawi K. Pregnancy outcomes among Syrian refugee and Jordanian women: a comparative study. Int Nurs Rev. 2017;64:584-92. [CrossRef]

4. Murray C, King G, Lopez AD, Tomijimia N, Krug EG. Armed conflict as a public health problem. BMJ. 2002;324:346-9. [CrossRef]

5. Abu Hamad Kh, Abed Y, Abu Hamad B. Risk factors associated with preterm birth in the Gaza Strip: hospital-based case control study. East Mediterr Health J. 2007;13:1132-41. [CrossRef]

6. Reese Masterson A, Usta J, Gupta J, Ettinger AS. Assessment of reproductive health and violence against women among displaced Syrians in Lebanon. BMC Womens Health. 2014;14:25. [CrossRef]
7. Kandasamy T, Cherniak R, Shah R, Yudin MH, Spitzer R. Obstetric Risks and Outcomes of Refugee Women at a Single Centre in Toronto. J Obstet Gynaecol Can. 2014;36:296-302. [CrossRef]

8. Büyüktiryaki $M$, Canpolat $F E$, Alyamac Dizdar E, Okur N, Kadıoğlu Şimşek G. Neonatal outcomes of Syrian refugees delivered in a tertiary hospital in Ankara, Turkey. Confl Health. 2015;9:38. [CrossRef]

9. Erenel H, Aydogan Mathyk B, Sal V, Ayhan I, Karatas S, Koc Bebek A. Clinical characteristics and pregnancy outcomes of Syrian refugees: a case-control study in a tertiary care hospital in Istanbul, Turkey. Arch Gynecol Obstet. 2017;295(1):45-50. [CrossRef]

10. Demirci H, Yildirim Topak N, Ocakoglu G, Karakulak Gömleksiz M, Ustunyurt E, Ulku Turker A. Birth characteristics of Syrian refugees and Turkish citizens in Turkey in 2015. Int J Gynaecol Obstet. 2017;137(1):63-6. [CrossRef]

11. Güngör ES, Seval O, İlhan G, Verit FF. Do Syrian refugees have increased risk for worser pregnancy outcomes? Results of a tertiary center in İstanbul. Turk J Obstet Gynecol. 2018;15(1):23-7. [CrossRef]

12. Ozel S, Yaman S, Kansu Celik H, Hancerliogullari N, Balci N, Engin Ustun Y. Obstetric Outcomes among Syrian Refugees: A Comparative Study at a Tertiary Care Maternity Hospital in Turkey. Rev Bras Ginecol Obstet. 2018;40(11):673-9. [CrossRef]

13. Turkay U, Aydın U, Calıskan E, Salıc M, Terzi H, Astepe B. Comparison of the pregnancy results between adolescent Syrian refugees and local adolescentTurkish citizens who gave birth in our clinic. J Matern Fetal Neonatal Med. 2018;25:1-6. [CrossRef]

14. Ganchimeg T, Ota E, Morisaki N, Laopaiboon M, Lumbiganon P, Zhang J, et al. Pregnancy and childbirth outcomes among adolescent mothers: a World Health Organization multicountry study. BJOG. 2014;121:40-8. [CrossRef]

15. Neal S, Matthews Z, Frost M, Fogstad H, Camacho AV, Laski L. Childbearing in adolescents aged 12-15 years in low resource countries: a neglected issue. New estimates from demographic and household surveys in 42 countries. Acta Obstet Gynecol Scand. 2012;91(9):1114-8. [CrossRef]

16. UN DESA, Statistics Division. SDG Indicators: Global Database. New York: UN DESA: 2017.

17. Huster KM, Patterson N, Schilperoord MC, Spiegel P. Cesarean Sections Among Syrian Refugees in Lebanon from December 2012/January 2013 to June 2013: Probable Causes and Recommendations. Yale J Biol. Med. 2014;87(3):269-88.

18. Satman I, Omer B, Tutuncu Y, Kalaca S, Gedik S, Dinccag N, et al. Twelve-year trends in the prevalence and risk factors of diabetes and prediabetes in Turkish adults. Eur. J Epidemiol. 2013;28(2):169-80. [CrossRef]

19. Goymen A, Altinok T, Uludag S, Sen C, Ocer F, Uzun $H$, et al. The role of maternal serum adiponectin levels in screening and diagnosis of gestational diabetes mellitus. Perinatal Journal. 2008;16(2):49-55. 